Heaney, R., \& Irlicht, L. (2007). The Impact of Occupational Health and Safety Policy on Firm Value. ECONOMIC PAPERS OF THE ECONOMIC SOCIETY OF AUSTRALIA, 26(4), 308-320.

C 2007 The Economic Society of Australia

This is the pre-peer reviewed version of the following article: , Heaney, R., \& Irlicht, L. (2007). The I mpact of Occupational Health and Safety Policy on Firm Value. ECONOMIC PAPERS OF THE ECONOMIC SOCIETY OF AUSTRALIA, 26(4), 308-320, which has been published in final form at http://doi.org/10.1111/j.1759-3441.2007.tb01017.x

This version was made available in the UWA Research Repository on the $14^{\text {th }}$ of November 2014 in compliance with the publisher's policies on archiving in institutional repositories.

Use of the article is subject to copyright law. 


\title{
THE IMPACT OF OCCUPATIONAL HEALTH AND SAFETY POLICY ON FIRM VALUE
}

\author{
by \\ RICHARD HEANEY* AND LAURENCE IRLICHT ${ }^{+}$
}

\begin{abstract}
There have been few studies that analyse the impact of OHS on the value of Australian firms and yet this is an important area of business for both small and large businesses. In this paper we pay particular attention to the impact of Victorian Workcover Authority prosecutions on listed Australian firms. USA based research shows that OHS prosecutions have a negative impact on firm value and we find some evidence to support the existence of negative share price reaction to OHS prosecution in our sample of listed Australian firms.
\end{abstract}

Key words: Occupational health and safety, share price.

JEL Code: G14, I18, J28.

\section{Acknowledgements}

The paper was written under the auspices of Syd Bone and Leo de Bever of VFMC and we thank the Department of Innovation, Industry and Regional Development (DIIRD), RMIT and the Melbourne Centre of Financial Studies (MCFS) for financial support provided under the Victoria Government - Industry Academic Research Internships scheme. We thank Craig Hughes, Norm Sinclair and the staff of VFMC for their support and guidance during this project. We also acknowledge the help and support of Ian Sargent, Dr Michelle Zorbas, Anthea Ryall and Bill Stavreski from the Victorian Workcover Authority for help with data collection and general comments. Further, we thank Amanda McCluskey of Portfolio Partners, Chris Fayers from Monash University, Rosalind McKay from ACSI and Melissa Axford, Health and Safety Consultant, RMIT University for their advice and comments.

\section{Contact Details}

* Richard Heaney, School of Economics and Finance, Business, RMIT University, level 12, 239 Bourke Street, Melbourne, 3000, Phone: 039925 5905, Fax: 039925 5905, Email: Richard.Heaney@ rmit.edu.au

${ }^{+}$Laurence Irlicht, Victorian Funds Management Corporation, Melbourne. 
This paper investigates the impact of occupational health and safety (OHS) policy on the share price of listed Australian firms. There has been a considerable resurgence in interest in corporate OHS policy and practises, particularly for institutional investors. ${ }^{1}$ For example, OHS policy forms an important part in evaluation of corporate sustainability policy (Cadbury, 2006), Corporate Social Responsibility (Australian Council of Super Investors Inc., 2005) and firm environment, social and governance (ESG) practice and performance.

It could also be argued that corporate OHS policy provides insight into management quality and this has certainly been argued in a recent mining industry analysis conducted by Clifford and Edney (2004) where it is stated that OHS should not be separated from other functions of the firm. It is possible that poor corporate OHS outcomes reflect a more general malaise in the firm's resource management. ${ }^{2}$ OHS policy is also important for the broader community. Australian work-related injury and disease costs are estimated at $\$ 31$ billion per year for the period, 2001-2002. ${ }^{3}$ While most OHS incidents have little direct impact on the firm, catastrophic events do occur. The 1998 Esso Longford gas explosion in Victoria provides a recent Australian

\footnotetext{
${ }^{1}$ Professional investors need to be aware of OHS issues, given the introduction of the Financial Services Reform Act, 2001 which specifically requires providers of financial products to disclose the impact of labour standards in their investment decisions (S.1013D.1.1, Labour standards and environmental, social and ethical considerations, Financial Services Reform Act, 2001). There is also an expectation that OHS should have an impact on professional investors (Westpac Group and the BT Financial Group, 2004) though a recent survey conducted by Anderson, Marshall and Ramsay (2006) notes a tendency for sporadic interaction between institutional investors and corporations rather than a conscious and continuing assessment of human resource issues.

${ }^{2}$ Poor OHS policy is generally argued to reflect poorly on the management of firm assets, particularly labour costs, though accidents can also result in lost production and damage to plant and machinery. The direct costs to the firm of poor OHS practices are reflected in terms of increased sick leave costs, higher staff turnover rates and increased wage levels relative to competitors though the indirect costs can also be considerable. While profit maximising behaviour suggests there is a trade off between safety and profits, relatively unsafe employers will face sanctions as well as higher labour costs. In a regulated, though otherwise competitive market, it is likely that these relatively unsafe firms will exit the industry in the longer term due to their higher costs.

${ }^{3}$ See the National Occupational Health and Safety Commission (2004).
} 
example and the BP refinery explosion in Texas in 2005, the Bhopal disaster in 1984 and the Seveso disaster in 1976 provide examples of disastrous industrial accidents occurring in other countries. These incidents have a severe impact on employees, investors, local residents and the environment.

We analyse the impact of OHS on firm value using an event study based on Victorian Workcover prosecution of listed Australian companies and their subsidiaries using a unique data set provided by the Victorian Workcover Authority. While there is no evidence of statistically significant negative abnormal returns with OHS prosecution there is evidence of a statistically significant proportion of the firms in the sample exhibiting negative returns on OHS prosecution. These results are not as strong as the USA based results, as reported by Fry and Lee (1989), though this difference may just reflect variation in OHS regulation between Australia and the USA. A literature review is provided in the following section, with a brief introduction to that Australian OHS environment is Section 3. Data description is provided in Section 4, with analysis discussed in section 5 and Conclusions drawn in Section 6.

\section{$2 \quad$ Literature Review}

There are two ways in which OHS can materially affect a company's performance. The first refers to actual "OHS incidents" such as disasters and other workplace accidents that can generate substantial costs for the company. The second arises from the higher monetary compensation required employees to compensate them for working in a relatively unsafe environment. 
The economic literature dealing with OHS and the relationship between work risks and compensation is considerable. First, individuals do not appear to treat safety at work any differently from safety in other facets of their life, for example safety while travelling (Jones-Lee, Hammerton and Philips, 1985). Second, individuals appear to demand greater levels of pay in compensation for lower levels of work safety (higher risk positions). Indeed, study of the impact of safety in the work place and its effect on wages has a long history in the economics literature. Perhaps the first to acknowledge this was Adam Smith who observed that there was a compensating differential between wages paid by low risk jobs and the wages paid by high-risk jobs. The empirical literature has tended to focus on the relationship between death, or injury rates, and wage levels (Cousineau, Lacroix and Girand, 1992, Hersch, 1998, Meng, 1989, Martinello and Meng, 1992, Viscusi, 1978). There have also been attempts to determine the marginal value of life (Gegax, Gerking and Schulze, 1991) with a more recent Australian estimate placing this value in the range of $\$ 11$ million to $\$ 19$ million (Miller, Mulvey and Norris, 1997). Third, quit rates are greater where job safety risks are high (Viscusi, 1979a). Thus, it is expected that firm value will be sensitive to OHS breeches due to the possibility of increased labour costs, the penalties arising from OHS prosecution and the cost of corrective action to avoid OHS problems in the future.

While there has been some activity in the economics literature in the OHS area there is growing finance practitioner interest, with a number of recent consulting studies dealing with sustainability and ESG practice and performance. These studies invariably refer to corporate OHS policy and practices. For example, Larsson, Mather and Dell (2007) and a closely related working paper, Westpac Investment 
Management (2000), provide one of the first attempts to assess the impact of OHS filters on portfolio performance of Australian firms. The top 150 Australian listed firms were filtered on the basis of OHS ratings supplied by the Monash University Accident Research Centre (MUARC) ${ }^{4}$, resulting in the exclusion of 51 of the 150 stocks. It was observed that the filtered portfolio outperformed the S\&P200 index over a 10-year back test period. The authors suggest that the link between OHS policy and share returns reflects superior management though this question was not addressed specifically in the paper.

Given the impact of OHS on the workplace and the environment, and the potential for underinvestment in this area, it is often argued that regulation is a key factor in ensuring that adequate OHS is maintained across a broad spectrum of companies. For example Carmichael (1986) shows that regulation can lead to an optimal outcome where it takes time for employees to learn about the true safety risks that underlie the job. Yet, Rea (1981) argues that there is a trade off where regulation covers both work place safety insurance and work place safety. Indeed, it is possible for insurance regulation to result in reduced levels of safety. These arguments are further developed in Lanoie (1991) who supports government OHS regulation under certain conditions.

The empirical literature dealing with the impact of government regulation is generally North American based and it is found that the regulations generated by the OHSA in the US (Viscusi, 1986) and similar bodies in Canada (Lanoie, 1992) have little real impact on injury rates. Thus, while in theory government OHS regulation may be

\footnotetext{
${ }^{4}$ Mansley (2002) provide some indication of the complexity of the task that the MUARC faced with the development of OHS rankings.
} 
value increasing in certain situations, for example where employees are not fully informed as to the true probability of injury, the empirical literature suggests that the US and Canada OHS regulation has little impact on injury rates. There is limited European or Australian economic research into these questions ${ }^{5}$ though Eichener (1997) proposes that OHS is one of the few areas where regulation has been successfully implemented in the European Union.

Failure to properly address OHS issues at the individual firm level can result in legal sanctions and there is evidence of considerable negative share market reaction to OHS sanctions in the US. For example Fry and Lee (1989) show that US listed firm value decreases around the date that Occupational Safety and Health Administration ${ }^{6}$ (OSHA) sanctions are reported in the wall street journal. They find that the decrease in value is considerably larger than the direct cost arising from the OSHA sanctions. ${ }^{7}$ Fry and Lee (1989) use a sample of 28 companies that were either listed on the NYSE or the American Stock Exchange. ${ }^{8}$ They initially identified a list of 63 announcements appearing in the Wall Street Journal Index over a period of 15 years, from 1973 to 1988 , but this was reduced to 28 announcements, mainly due to the existence of other announcements around the citation publication date. ${ }^{9}$ Statistically and economically significant abnormal negative equity returns are generated by these companies around the prosecution announcement date $(-2.1 \%$ over the three day event period). The decrease in share value is far in excess of the OSHA penalties levied on

\footnotetext{
${ }^{5}$ For example the ANU based National Research Centre for OHS Regulation (http://www.ohs.anu.edu.au/ohs/index.php) research tends to focus on the legal issues rather than the economic issues with little empirical analysis.

${ }^{6}$ http://www.osha.gov/.

${ }^{7}$ This result is important as Viscusi (1979) found that in the USA the level of OSHA sanctions levied in the 1970s did not have a significant impact on injury rates after controlling for other factors.

${ }^{8}$ The date the OSHA publishes its citation in the Wall Street Journal is used as the announcement date in this study.

${ }^{9}$ These were generally dividend and acquisition announcements.
} 
the firms. Fry and Lee (1989) suggest that this considerable penalty reflects the expected cost of correcting the OHS problem as well as the expected cost of lawsuits arising from the breech of OHS regulations. These results certainly beg the question as to what impact OHS prosecutions have on Australian listed companies.

\section{$3 \quad$ OHS regulation in Australia}

At present the responsibility for regulation of OHS in Australia lies with the separate states and the Commonwealth, with the Australian Safety and Compensation Council (ASCC) as the national coordinating body. ${ }^{10}$ The legislation is broadly based on the Robens report ${ }^{11}$ and this proposes that responsibility for OHS rests jointly with government, management and employees, though there is evidence of considerable variation in legislation across Australia. This approach is quite different from the prescriptive regulatory approach followed in the USA and Canada. While there are undoubted benefits arising from taking a consensus based approach, there is also considerable uncertainty about what exactly constitutes a safe workplace. Regardless, Australian firms are subject to regulation and need to formulate policies to ensure that their employees work in a safe environment and so firm specific and industry wide experience has developed to deal with this environment. ${ }^{12}$

Nevertheless, there are few OHS prosecutions brought against listed companies in Australia, consistent with the USA (Fry and Lee, 1989). Further, while the OSHA approach to occupational health and safety regulation applied in USA is quite

\footnotetext{
${ }^{10}$ National Occupational Health and Safety Commission (NOHSC) was abolished in 2005 and replaced by the Australian Safety and Compensation Council (ASCC).

${ }^{11}$ Report of the Committee on Safety and Health at Work 1970-1972, HMSO, London, 1972.

${ }^{12}$ The ANU based National Research Centre for OHS Regulation provides a web site that deals with OHS issues in Australian and overseas (http://www.ohs.anu.edu.au/ohs/index.php). This site also provides access to a set of working papers dealing with legal issues pertinent to OHS regulation both in Australia and overseas.
} 
different from the Australian OHS system there are important similarities between citations and Australian Workcover authority prosecutions. For example, it is difficult to predict whether prosecution will take place once an injury occurs. It is also difficult to ascertain whether the company will be found liable once the parties appear before a magistrate. Finally, prediction of the actual penalty levied on the firm is further complicated by the willingness of the courts to recognise actions taken by firms in correcting OHS problems between the time when the OHS breech is identified, or an accident occurs, and the time at which the firm faces the magistrate. Johnstone (2002), in particular, argues that rapid response to correcting OHS problems provides a viable defence in OHS proceedings before the Australian courts.

\section{$4 \quad$ Data}

The Victorian Workcover Authority provide a list of all prosecutions including the name of the company, the offence date, the prosecution date, the magistrate, a brief description of the offence, the amount of the fine and the costs imposed. ${ }^{13}$ The data is provided in a set of PDF files, one for each year, spanning the period from 1999 though to 2005. Listed companies are identified by selecting all limited companies appearing in the reports and then checking these names against companies listed on the Australian Stock Exchange around the offence date and the prosecution date. While this paper is concerned with listed company offences, a number of the companies subject to prosecution are subsidiaries of listed companies and so it is necessary to identify the listed holding companies at the time of the offence or the

\footnotetext{
${ }^{13}$ The workcover authorities in Queensland, NSW and WA were also contacted though these authorities either did not respond to the specific data request or were not prepared to provide data of the sort provided by the Victorian Workcover Authority. The workcover authorities in the smaller states and territories were not approached due to their size and available resources and also due to the lower levels of listed company prosecutions that take place in these regions. We thank Bill Stravreski at the Victorian Workcover Authority for his advice and help in collection of the Victorian workcover prosecution data and also on advice about possible data sources in Australia.
} 
prosecution. It is not feasible to access lists of subsidiaries for all listed companies back to 1999 but it is possible to access subsidiary lists for the larger listed Australian firms for the years 2001, 2002, 2003, 2004 and 2005 using the historical data from the OSIRIS data disks ${ }^{14}$. Holding companies are identified using these lists, and share price information is collected for these listed holding companies. One possible limitation of the study is that some subsidiaries of very small listed companies and so we were not able to obtain share price data for these firms. Further, some companies were prosecuted prior to 2000 and so are excluded due to lack of data. These limitations of the data set should be borne in mind in the following discussions though it is not expected that they will bias the results of analysis in any particular way.

The full prosecution sample includes 59 prosecutions. There are 13 firms with more than one prosecution date and 11 firms with more than one offence date. The shortest time between any two consecutive prosecution dates for a particular company is 49 days with an average of 530 days separating the prosecution dates. Similarly, the shortest time between any two consecutive offence dates for a company is 120 days with an average of 489 days. Thus, there is no overlap for the purposes of the event study period for any of the offence or prosecution event periods. Further, there is no overlap between the offence event and prosecution event period for any of the prosecutions. The average time between offence date and prosecution date for the firms in the sample is 758 days with a minimum of 142 days. Finally, while the prosecution date is always on a share market trading date the offence dates can occur over the weekend and where this occurs the offence date is set equal to the following Monday, the next feasible trading day. Some dates are lost because of missing share

\footnotetext{
${ }^{14}$ The OSIRIS disks include information on the largest 897 firms listed on the Australian stock exchange in the 2002 disk increasing to over 1470 companies in the 2005 disk. We were not able to obtain data disks covering the period prior to 2002 .
} 
price data, giving a final sample with 50 prosecution dates (31 firms) and 43 offence dates (28 firms) for which share price data is available. Detailed information about the sample is reported in Table 1, Panels A, B and C.

[Insert Table 1 about here]

For the full 59 prosecutions, the average fine and court costs levied against firms in the sample amount to $\$ 29,991$ and $\$ 3,506$ respectively, giving an average total cost of $\$ 33,497$ (Table 1, Panel B). Virtually all the firms in the study were eventually convicted and fined and court costs were levied against these firms in virtually all cases. There are some firms that were not convicted, though these companies were generally fined nevertheless and costs were also generally levied against them. Four of the prosecutions involved committal to the county court and, while there is clearly no fine determined at this stage, this action highlights the seriousness of the offence and so these event dates were included in the sample. Charges were withdrawn in a further three instances and neither fines nor costs were levied against these firms. Nevertheless, while the action taken against these particular firms is terminated these three events remain part of the sample because of the comparative seriousness of the original injury or the breech of ruling. The costs levied against the firms in this sample are relatively small, given the size of the firms, yet these firms often incur considerable expenditure in correcting the OHS problem that led to the breech prior to the prosecution date. Such corrective action is often noted in the magistrate's comments. Further, there is also the possibility of costly civil court action arising from OHS accidents (Fry and Lee, 1989). Thus, the magnitude of the fines and costs 
that are levied against the firms may not be particularly informative with respect to the final cost of a particular OHS event for a firm.

\section{$5 \quad$ Analysis}

We analyse the impact of OHS on firm value given Victorian Workcover offence and prosecution dates using an event study approach. The event study follows Fry and Lee (1989) with the objective of ascertaining the share market reaction to a breech of Workcover rules or the injury or death that resulted in the prosecution. Given that Fry and Lee (1989) identified a statistically significant market reaction to the OSHA citations against listed firms when announced in the Wall Street Journal it is of interest to see whether a similar effect exists for Victorian Workcover reported offence dates and prosecution dates.

The initial sample of firms is filtered to remove those firms with material announcements made during the event period using Australian stock exchange announcement information obtained from SIRCA ${ }^{15}$. This identifies market sensitive information releases for all listed Australian firms. The market sensitive announcements generally deal with mergers, acquisitions or release of financial reports. This filter reduces the sample for offence announcements from 43 to 23 event observations and the sample for prosecution announcements from 50 to 25 event observations. The reduction in sample size due to market sensitive announcements and the fairly small final sample were also apparent in the Fry and Lee (1989) USA based study.

\footnotetext{
${ }^{15}$ http://www.sirca.org.au/.
} 
The event study follows standard practice beginning with choice of an asset-pricing model to calculate expected returns over the event period. We use the market model and the historical average return in estimating expected return. Expected returns are deducted from observed security returns on each of the days in the chosen event period to give a set of abnormal returns and these are calculated for each of the companies in the sample. The abnormal returns are organised by event date, averaged across the firms and the cumulative average abnormal returns (CARs) are calculated for each date in the event period. There are three CARs used in the study, (1) the event date, (2) the event day and the previous day (two days) and (3) the event day, the previous day and the day before that (three days).

The expected return model parameters are estimated using returns drawn from the 250 trading day period prior to the event date, starting from the eleventh day prior to the event date and proceeding back to the $260^{\text {th }}$ day prior to the event date. We choose a ten day gap from the event date to the estimation period to ensure that event date share market activity does not bias the parameters used in the estimation of expected return for the firm. The market model is the first expectations model used in analysis. It takes the form:

$$
A R_{i t}=R_{i t}-E\left(R_{i t}\right)=R_{i t}-\alpha-\beta R_{m t}
$$

Where $A R_{i t}$ is the calculated abnormal return for day $t, R_{i t}$ is the realised return for day $t, E\left(R_{i t}\right)$ is the expected return for company $i$ on day $t, R_{m t}$ is the market return for day $t$ and $\alpha, \beta$ are the market model parameters estimated using company and equity market returns for the 250 trading day estimation period. The second expectations model assumes fixed returns over time, with the average return over the 250-day estimation period being used to estimate expected return, $\bar{R}$. 


$$
A R_{i t}=R_{i t}-E\left(R_{i t}\right)=R_{i t}-\bar{R}
$$

We rely on the Victorian Workcover offence date and prosecution date for the event dates. There is little consistent reporting of OHS prosecutions in the press and so the Victorian Workcover prosecution data appears to be the only reasonably complete, freely available and reliable source of announcement dates. Further, the prosecution date is similar to the OSHA citation date used in the Lee and Fry (1989) study. While a statistically negative share market reaction is expected if the Workcover offence is viewed as bad news, it is also possible that the there will be negligible share price impact, given the small size of the fines relative to firm value, and assuming that the safety problems have already been corrected and there is a negligible expected cost attached to future litigation. For the prosecution date, it is also possible that the price could increase on the announcement date where the market has over estimated the negative impact of the OHS prosecution prior to the event date. ${ }^{16}$

The OLS market model and mean return based event study results are reported in Table 2. We report the CAR, CAR t-statistic, the percentage of firms with negative returns and the binomial test probability associated with the proportion of the firms with CAR less than zero. The abnormal returns around the offence date are not statistically significantly different from zero on the basis of t-tests. This is inconsistent with the argument that an OHS offence, such as an injury or a breech of the rules, results in a statistically significant decrease in firm value though most of the estimates reported in Table 2 are negative indicating that the average market reaction

\footnotetext{
${ }^{16} \mathrm{We}$ thank one of the reviewer's for highlighting this possibility.
} 
is negative. The only exception is the offence date one-day CARs which are positive for both the market model and the mean adjusted expectation return models.

[Insert Table 2 about here]

We obtain a different story with application of the non-parametric binomial test to the data. There are statistically significantly more firms in the sample reporting a negative abnormal return on the prosecution date than those reporting a positive or zero return. The prosecution date appears to be the key date for this analysis with neither the three day CAR nor the two day CAR exhibiting statistically significant binomial test results. It appears that the announcement of the OHS prosecution results in negative abnormal returns for considerably more than half of the firms in the sample. We also find similar results for the offence date analysis though in this case the three day CAR shows statistically significantly more negative than positive values. The effect appears to be located mainly two days prior to the recorded offence date given the results for the one day and two day CARs.

Thus, while there is evidence of a negative market reaction on the prosecution day and on the days preceding the recorded offence day, this share price reaction is not statistically significant. Yet, the incidence of negative returns across the sample, is statistically important on the prosecution date and somewhat prior to the recorded offence date. The lack of statistically significant CARs for the event period is unexpected though it may be explained, at least partially, by the approach taken by Victorian workcover in managing OHS regulation. There is also some evidence to suggest that the cost of serious injury is lower in Victoria relative to the other states 
and territories of Australia. ${ }^{17}$ Essentially, if OHS regulation is enforced in an efficient manner then firms may choose to maintain relatively strong OHS practices and policies which results in a lower probability of successful civil litigation against these firms, particularly where reasonable behaviour determines the final penalty from litigation. Other state Workcover agencies were contacted in an effort to expand the sample size beyond Victoria and to test whether there is a state based difference in market reaction to OHS announcements but these agencies were not forthcoming with data. Thus, we are unable to follow up on this line of research. While all of the state agencies provide excellent summary information on their activities, only Victoria is currently prepared to supply the level of detail required for the analysis conducted in this paper.

Finally, it is clear from the summary notes appearing in the Victorian Workcover prosecution details that many of the firms were quick to correct safety problems and this was particularly evident for the larger listed companies. This strategy may provide a further reason for the lack of statistically significant negative abnormal returns on prosecution. As a result of this proactive behaviour Victorian firms may provide both a safer work place for their employees and also face a considerably lower share price reaction on the OHS prosecution date.

\section{Conclusions}

This study adds to the very limited empirical research in the area of OHS in Australia, using a unique data set of Victorian Workcover prosecutions over the period from

\footnotetext{
${ }^{17}$ The cost of work related injury and illness as a percentage of state GDP was lowest for Victoria in 2000-1 financial year at 3.4\% (Table 2.3a in National Occupational Health and Safety Commission, 2004)
} 
1999 to 2005 . While there is evidence of negative share market returns around the offence and prosecution dates these returns are not statistically significantly different from zero. Yet, there is evidence that a statistically significant proportion of the sample did exhibit negative returns on the prosecution date as well as around the recorded offence date.

Clearly, the size of the penalties that are awarded against the firms are small when compared with the size of the firms involved and so it is likely that the actual fine and costs awarded against the firm has little direct impact on the value of the firm's shares. This is also noted by Fry and Lee (1989) in their US analysis. They suggest that the cost of litigation that arises from injuries and the cost of correcting OHS problems are the most likely explanation for the market reaction identified in their paper. While this may be true for the US, the costs generated by civil and criminal litigation, arising from OHS breeches and injury, are comparatively small for listed firms in Australia. Further, there is a tendency for Australian firms to correct OHS problems when they arise. This is particularly evident for the larger listed companies and this action has proved useful as a defence in Australian OHS actions. There may also be an element of signalling in Workcover prosecutions as the existence of a prosecution could flag more general problems in the firm's management and so larger firms may actively seek to avoid OHS prosecution.

Each of these arguments supports the lack of a statistically significant share market reaction on the offence date and the prosecution date. Perhaps the nature of the Australian workcover system fosters a more careful approach by listed firms to development of OHS policies and procedures compared with the USA for example. It 
is possible that the Australian approach to OHS regulation, which encourages the adoption of best practice at the individual firm level, coupled with a court system that encourages prompt response to failures in existing OHS policy and procedure results in less share market sensitivity to OHS prosecutions. We leave analysis of this proposition to future research. 


\section{REFERENCES}

Anderson, K., S.Marshall and I. Ramsay (2006) "Do Australian Institutional Investors Aim to Influence the Human Resource Practices of Investee Companies?" Paper delivered at Corporate Governance and the Management of Labour: Australian Perspectives Workshop, Melbourne, Thursday 7th \& Friday 8th December 2006, pp. 1-89.

Becker, G. S. (1962) "Investment in Human Capital: A Theoretical Analysis",

Journal of Political Economy, 70, pp. 9-49

Black, F. (1985) "Noise", Journal of Finance, 41, pp. 529-543

Blume, M. E., I. Friend (1974) "The Asset Structure of Individual Portfolios and Some Implications for Utility Functions", Journal of Finance, 30, pp. 585-603

Cadbury, A. (2006) "Corporate Social Responsibility", $21^{\text {st }}$ Century Society, 1, pp. 521.

Canner, N., N. G. Mankiw and D. N. Weil (1997) “An Asset Allocation Puzzle”, American Economic Review, 87, pp. 181-191

Carmichael, H. L. (1986) "Reputations for Safety: Market Performance and Policy Remedies", Journal of Labor Economics, 4, pp. 458-472.

Clifford, R. and W. Edney (2004) "Safety in Numbers", ABN-AMRO, Mining, 22 December, pp. 1-6.

Cousineau, J-M., R. Lacroix and A.-M. Girand (1992) "Occupational Hazard and Wage Compensating Differentials", Review of Economics and Statistics, 74, pp. 166-169.

Eichener, V. (1997) "Effective European Problem-Solving: Lessons from the Regulation of Occupational Safety and Environmental Protection", Journal of European Public Policy, 4, pp. 591-608.

Fry, C. L. and I. Lee (1989) "OSHA Sanctions and the Value of the Firm", Financial Review, 24, pp. 599-610.

Gegax, D., S. Gerking and W. Schulze (1991) "Perceived risk and the marginal value of safety", Review of Economics and Statistics, 73, pp. 589-596.

Hashimoto, M. (1981) "Firm-Specific Human Capital as a Shared Investment", American Economic Review, 71, pp. 475-482

Hersch, J. (1998) “Compensating Differentials for Gender-Specific Job Injury Risks", American Economic Review, 88, pp. 598-607.

Jones-Lee, M. W., M. Hammerton and P. R. Philips (1985) "The Value of Safety: Results of a National Sample Survey", Economic Journal, 95, pp. 49-72.

Johnstone, R. (2002) Safety, "Courts and Crime, National Centre for OHS Regulation", Working Paper No. 6, pp. 1-33.

Orlitzky, M., F. L. Schmidt and S. L. Rynes (2003) "Corporate Social and Financial Performance: A Meta-analysis”, Organisational Studies, 24, pp. 403-441.

Lanoie, P. (1991) "Occupational Safety and Health: a Problem of Double or Single Moral Hazard", Journal of Risk and Insurance, 58, pp. 80-100.

Lanoie, P. (1992) "The Impact of Occupational Safety and Health Regulation on the Risk of Workplace Accidents", Journal of Human Resources, 27, pp. 643-660.

Larsson, T. J., E. Mather and G. Dell (2007) "To Influence Corporate OH\&S Performance through the Financial Market”, International Journal of Risk Assessment and Management, 7, pp. 263-271. 
Mansley, M. (2002) "Health and Safety Indicators for Institutional Investors", A report to the Health and Safety Executive by Claros Consulting, 28th February 2002, pp. 1-37.

Martinello, F. and R. Meng (1992) "Workplace Risks and the Value of Hazard Avoidance", Canadian Journal of Economics, 25, pp. 333-345.

Mayers, D. (1973) "Nonmarketable Assets and the Determination of Capital Asset Prices in the Absence of a Riskless Asset", Journal of Business, 46, pp. 258267.

Meng, R. (1989) "Compensating Differences in the Canadian Labour Market", Canadian Journal of Economics, 22, pp. 413-424.

Miller, P., C. Mulvey and K. Norris (1997) "Compensating differentials for risk of death in Australia", Economic Record, 73, pp. 363-373.

Monash Governance Research Unit (2005) "Corporate Social Responsibility: Guidance for Investors”, Discussion Paper prepared for Australian Council of Super Investors Inc., pp. 1-3.

National Occupational Health and Safety Commission (2004) "The Cost of Work Related Injury and Illness for Australian Employers", Workers and the Australian Community, Canberra, pp. 1-43. (http://www.ascc.gov.au/.pdf)

Palacios-Huerta I. (2003) "An Empirical Analysis of the Risk Properties of Human Capital Returns", American Economic Review, 93, pp. 948-964.

Rea, S. A. (1981) "Workmen's Compensation and Occupational Safety Under Imperfect Information", American Economic Review, 71, pp. 80-93.

Viscusi, W. K. (1978) "Wealth Effects and Earnings Premiums for Job Hazards", Review of Economics and Statistics, 60, pp. 408-416.

Viscusi, W. K. (1979a) "Job Hazards and Worker Quit Rates: An Analysis of Adaptive Worker Behavior”, International Economic Review, 20, pp. 29-58.

Viscusi, W. K. (1979b) "The Impact of Occupational Safety and Health Regulation", Bell Journal of Economics, 10, pp. 117-140.

Viscusi, W. K. (1986) "The Impact of Occupational Safety and Health Regulation", Rand Journal of Economics, 17, pp. 567-580.

Westpac Group and the BT Financial Group (2004) "Workplace Health and Safety Governance", Position paper, pp. 1-6.

Westpac Investment Management (2000) "Linking Screened Investments to Shareholder Value: An Overview of Screened Investments and the Potential for Impact on Shareholder Value", Investor Relations Forum 2000, paper prepared by Erik Mather; Australia: WIM, pp. 1-17. 


\section{Table 1, Analysis of Workcover Prosecution Information}

Panels A, B and C provide information on the sample of Victorian Workcover prosecutions that were brought against listed companies, or their subsidiaries, identified in this study. Panel A is summary of the number of prosecutions organised by the year in which court prosecution was finalised. Panel B provides summary statistics on the fines and court costs that were levied against the firms in this study. Panel C provides a summary of the number of prosecutions organised by the year in which offence took occurred. Note: Conv. = company convicted of charge, No conv. = company not convicted of charge, Other = generally company has been committed to a county court with Total $=$ Conv. + No conv. + Other. Death $=$ prosecution concerns the death of an employee, Injury = prosecution involved the injury of an employee, Breech = prosecution was for breech of safety ruling with Total $=$ Death + Injury + Breech, Missing prices $=$ the number of events with no share price information. The average fine, average court cost and average total cost to the firm are expressed in dollars and refer to the fines and costs that are levied on the firms by the courts.

Panel A: Summary of events by prosecution date

\begin{tabular}{l|c|ccc|ccc|}
\hline Year & Total & Conv. & No conv. & Other & Death & Injury & Breech \\
\hline 1999 & 8 & 8 & 0 & 0 & 0 & 7 & 1 \\
2000 & 2 & 2 & 0 & 0 & 0 & 1 & 1 \\
2001 & 8 & 7 & 1 & 0 & 0 & 8 & 0 \\
2002 & 8 & 6 & 2 & 0 & 2 & 6 & 0 \\
2003 & 15 & 10 & 3 & 2 & 5 & 9 & 1 \\
2004 & 11 & 8 & 2 & 1 & 3 & 5 & 3 \\
2005 & 7 & 4 & 2 & 1 & 1 & 4 & 2 \\
\hline Total & 59 & 45 & 10 & 4 & 11 & 40 & 8 \\
\hline Missing prices & 9 & 7 & 2 & 0 & 1 & 8 & 0 \\
\hline Available Obs. & 50 & 38 & 8 & 4 & 10 & 32 & 8 \\
\hline
\end{tabular}

Panel B: Average costs set by the courts

\begin{tabular}{l|ccc}
\hline & $\begin{array}{c}\text { Average fine (\$’s) } \\
\text { per prosecution }\end{array}$ & $\begin{array}{c}\text { Average court costs }(\$ ’ s) \\
\text { per prosecution }\end{array}$ & $\begin{array}{c}\text { Average total } \\
\text { cost to the firm (\$'s) } \\
\text { per prosecution }\end{array}$ \\
\hline Year & 26500 & 1454 & 27954 \\
1999 & 35000 & 2206 & 34706 \\
2000 & 38375 & 5073 & 43448 \\
2001 & 31625 & 4283 & 35908 \\
2002 & 38682 & 8040 & 46722 \\
2003 & 32444 & 2930 & 35375 \\
2004 & 42000 & 0 & 42000 \\
2005 & 34696 & 4056 & 38752 \\
\hline Total & & &
\end{tabular}


Panel C: Summary of events by offence date

\begin{tabular}{l|c|ccc|ccc|}
\hline Year & Total & Conv. & No conv. & Other & Death & Injury & Breech \\
\hline 1995 & 1 & 1 & 0 & 0 & 0 & 1 & 0 \\
1996 & 2 & 2 & 0 & 0 & 0 & 1 & 1 \\
1997 & 6 & 6 & 0 & 0 & 0 & 6 & 0 \\
1998 & 4 & 4 & 0 & 0 & 2 & 2 & 0 \\
1999 & 7 & 6 & 1 & 0 & 2 & 5 & 0 \\
2000 & 6 & 3 & 2 & 1 & 1 & 5 & 0 \\
2001 & 9 & 7 & 1 & 1 & 1 & 8 & 0 \\
2002 & 9 & 8 & 1 & 0 & 2 & 5 & 2 \\
2003 & 11 & 6 & 3 & 2 & 3 & 6 & 2 \\
2004 & 2 & 1 & 1 & 0 & 0 & 0 & 2 \\
No date provided & 2 & 1 & 1 & 0 & 0 & 1 & 1 \\
\hline Total & 59 & 45 & 10 & 4 & 11 & 40 & 8 \\
\hline Missing prices & 16 & 11 & 3 & 2 & 4 & 11 & 1 \\
Available Obs. & 43 & 34 & 7 & 2 & 7 & 29 & 7 \\
\hline
\end{tabular}




\section{Table 2, Share market reaction to OHS event}

The event period cumulative average abnormal returns are reported using the data set that excludes firms with market sensitive announcements during the event period. There are three cumulative average abnormal returns (CARS) reported in the table. The first is the event day (t). The second spans the two days from $t-1$ to the event day (t) and the third spans the three days from $\mathrm{t}-2$ to the event day $(\mathrm{t})$. An expected return estimate is required for calculation of the abnormal returns for each firm. MM refers to the use of the market model in estimating expected returns and Mean refers to the use of the historical average return as the expected return in calculation of abnormal returns. The term CAR $=$ cumulative average abnormal return, $t$-statistic $=$ statistical test on the cumulative average abnormal return, $\%$ negative is the percentage of the firms with negative abnormal returns on the event day and the Binomial test prob. is the probability from the binomial test for a median of a zero cumulative average abnormal return. Note: $* *(*)$ significant at the 5\% (10\%) level of significance.

\begin{tabular}{|c|c|c|c|c|}
\hline Event period & $\begin{array}{c}\text { Prosecution } \\
\text { date }(M M)\end{array}$ & $\begin{array}{l}\text { Prosecution } \\
\text { date (Mean) }\end{array}$ & $\begin{array}{c}\text { Offence date } \\
(M M)\end{array}$ & $\begin{array}{c}\text { Offence date } \\
\text { (Mean) }\end{array}$ \\
\hline $\begin{array}{l}\text { One day event period } \\
\text { Event day }(\mathrm{t})\end{array}$ & & & & \\
\hline CAR & -0.0055 & -0.0043 & 0.0038 & 0.0014 \\
\hline t-statistic & -1.36 & -1.01 & 0.89 & 0.31 \\
\hline$\%$ negative & 73.91 & 73.91 & 39.13 & 39.13 \\
\hline Binomial test prob. & $0.04 * *$ & $0.04 * *$ & 0.40 & 0.40 \\
\hline $\begin{array}{l}\text { Two day event period } \\
\text { Day t-1 to event day (t) }\end{array}$ & & & & \\
\hline CAR & -0.0049 & -0.0026 & -0.0016 & -0.0027 \\
\hline t-statistic & -1.07 & -0.52 & -0.27 & -0.42 \\
\hline$\%$ negative & 60.87 & 56.52 & 60.87 & 56.52 \\
\hline Binomial test prob. & 0.69 & 1.00 & 0.40 & 0.68 \\
\hline $\begin{array}{l}\text { Three day event period } \\
\text { Day } t-2 \text { to event day }(\mathrm{t})\end{array}$ & & & & \\
\hline CAR & -0.0069 & -0.0050 & -0.0036 & -0.0064 \\
\hline t-statistic & -1.34 & -0.92 & -0.62 & -1.06 \\
\hline$\%$ negative & 65.22 & 60.87 & 69.57 & 73.91 \\
\hline Binomial test prob. & 0.23 & 0.42 & $0.09^{*}$ & $0.03 * *$ \\
\hline
\end{tabular}

